ISSN 0258-7122

Bangladesh J. Agril. Res. 36(1) : 151-163, March 2011

\title{
QUALITY OF TOMATO AS INFLUENCED BY BORON AND ZINC IN PRESENCE OF DIFFERENT DOSES OF COWDUNG
}

\author{
M. A. SALAM ${ }^{1}$, M. A. SIDDIQUE ${ }^{2}$, M. A. RAHIM ${ }^{3}$ \\ M. A. RAHMAN ${ }^{4}$ AND M. A. GOFFAR ${ }^{5}$
}

\begin{abstract}
The experiment was carried out at the Vegetable Research Farm of the Horticulture Research Centre, Bangladesh Agricultural Research Institute, Joydebpur, Gazipur to investigate the effect of boron, zinc, and cowdung on quality of tomato. There were 16 treatments comprising four rates of boron and zinc viz., $\mathrm{B}_{0} \mathrm{Zn}_{0}$. $\mathrm{B}_{1.5} \mathrm{Zn}_{2} \mathrm{~B}_{2} \mathrm{Zn}_{4}$ and $\mathrm{B}_{2.5} \mathrm{Zn}_{6} \mathrm{~kg} / \mathrm{ha}$ and four rates of cowdung viz., $\mathrm{CD}_{0}, \mathrm{CD}_{10}, \mathrm{CD}_{15}$, and $\mathrm{CD}_{20} \mathrm{t} / \mathrm{ha}$. Every plot received $253 \mathrm{~kg} \mathrm{~N}, 90 \mathrm{~kg} \mathrm{P}$, $125 \mathrm{~kg} \mathrm{~K}$, and $6.6 \mathrm{~kg} \mathrm{~S}$ per hectare. The results reflected that the highest pulp weight (90.24\%), dry matter content (5.82\%), ascorbic acid (11.2 mg/100g). lycopene content $(147 \mu \mathrm{g} / 100 \mathrm{~g})$, chlorophyll-a $(42.0 \mu \mathrm{g} / \mathrm{l00 \textrm {g }})$, chlorophyll-b $(61.0 \mu \mathrm{g} / 100 \mathrm{~g})$, boron content $(36 \mu \mathrm{g} / \mathrm{g})$, zinc content $(51 \mu \mathrm{g} / \mathrm{g})$, marketable fruits at 30 days after storage (74\%) and shelf life (17 days) were recorded with the combination of $2.5 \mathrm{~kg} \mathrm{~B} / \mathrm{ha}+6 \mathrm{~kg} \mathrm{Zn/ha,} \mathrm{and} 20 \mathrm{t} / \mathrm{ha}$ cowdung.
\end{abstract}

Keywords: Quality of tomato, boron and zinc, doses of cowdung.

\section{Introduction}

Tomato (Lycopersicon esculentum Mill.) is one of the most important and popular vegetables in Bangladesh. It ranks third in the world's vegetable production, next to potato and sweet potato, placing itself first as processing crop among the vegetables. It is a cheap source of vitamin-C. Tomato covers about $9.8 \%$ of the area under total winter vegetables in Bangladesh and its yield was $6.98 \mathrm{t} / \mathrm{ha}$ in the country during the year 2005-06 (BBS, 2007). Adequate supply of nutrient can increase the yield, fruit quality, fruit size, keeping quality, colour, and taste of tomato (Shukla and Naik, 1993). Micronutrient deficiencies is one of the major limiting factors for crop production in Bangladesh (Tadano, 1985). Among the micronutrients, boron and zinc play an important role in improving the yield and quality of tomato in addition to checking various diseases and physiological disorders (Magalhaes et al., 1980). Demoranville and Deubert (1987) reported that fruit shape, yield, and shelf life of tomato were affected by boron deficiency. Zinc mainly functions as the metal component of a series of enzymes. Zinc deficiency is thought to restrict RNA synthesis, which in turn inhibits protein synthesis (Katyal and Randhawa, 1983). Balasubrarnaniam et al.

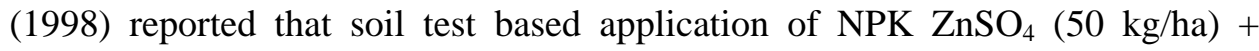

\footnotetext{
${ }^{1 \& 5}$ Senior Scientific Officer, Horticulture Research Centre, Bangladesh Agricultural Research Institute (BARI), Gazipur 1701, ${ }^{2,3 \& 4}$ Professor, Department of Horticulture, Bangladesh Agricultural University (BAU), Mymensingh, Bangladesh.
} 
Borax $(10 \mathrm{~kg} / \mathrm{ha})+$ composted coir pith (5 t/ha) gave the highest dry matter, content and uptake of nutrients of tomato. Kumar (2003) reported that application of FYM at 25 t/ha + 150\% NPK (150:112:82.5 kg/ha NPK) in tomato was the best for obtaining higher values in respect of growth, yield, and quality of tomato.

To improve the quality of tomato, there should have the technologies which will eventually fulfill the growers as well as consumers' need. Studies on management practices, particularly on the management of boron and zinc would help increasing quality of tomato. Available information in this regard under Bangladesh conditions is inadequate. The present study was, therefore, conducted in order to find out the influence of boron and zinc in presence of different doses of cowdung on the quality of tomato.

\section{Materials and Method}

The study was carried out at the Vegetable Research Farm of the Horticulture Research Centre, BARI during the period from October 2006 to April 2007. The experimental area is characterited by relatively scanty rainfall, low humidity, low temperature, short day, and long clear sunshine period during October to April. The experimental plot belongs to Madhupur Tract (AEZ-28). The soil $\mathrm{P}^{\mathrm{H}}$ was 6.4. having $1.64 \%$ organic mater, $0.087 \%$ total $\mathrm{N}, 29 \mu \mathrm{g} / \mathrm{ml}$ available $\mathrm{P}, 0.11$ meq/100g exchangeable K, $0.22 \mu \mathrm{g} / \mathrm{g} \mathrm{B}$, and $1.8 \mu \mathrm{g} / \mathrm{g} \mathrm{Zn}$. The study consisted of four levels of boron and zinc viz., $\mathrm{B}_{0} \mathrm{Zn}_{0}, \mathrm{~B}_{1.5} \mathrm{Zn}_{2.0}, \mathrm{~B}_{2.0} \mathrm{Zn}_{4.0}, \mathrm{~B}_{2.5} \mathrm{Zn}_{6.0} \mathrm{~kg} / \mathrm{ha}$ and four levels of cowdung viz., $0,10,15$, and $20 \mathrm{t} / \mathrm{ha}$. Thus there were 16 treatment combinations. In addition to the levels of boron, zinc, and cowdung under investigation, $253 \mathrm{Kg} \mathrm{N}, 90 \mathrm{Kg} \mathrm{P}, 125 \mathrm{Kg} \mathrm{K}$, and $6.6 \mathrm{Kg}$ S (550 kg urea, $450 \mathrm{Kg}$ TSP, $250 \mathrm{Kg}$ MoP, $120 \mathrm{Kg}$ gypsum per hectare) were applied. The sources of boron and zinc were boric acid and zinc oxide, respectively. The experiment was laid out in a RCB design with three replications, the unit plot being $2.4 \times 2.4 \mathrm{~m}$. Half of the quantity of cowdung, the entire quantity of TSP, gypsum, and $1 / 3$ MoP were applied during final land preparation. The remaining cowdung, entire boron, and zinc were applied during pit preparation. The entire urea and the rest of MoP were applied in three equal installments at 15, 30, and 50 days after transplanting. The test variety was BARI Tomato-9. Inter cultural operations were done as and when necessary. Data were collected on number of filled seeds per fruit, pulp weight, dry matter content, total soluble solid (TSS), acidity (Rangana,1994), ascorbic acid, lycopene content, chlorophyll- a and chlorophyllb according to Nagata et al.(1992), boron content (Hunter, 1980), zinc content (Rahayu et al., 2001), percent marketable fruit and shelf life (Mondal, 2000). From the middle rows of each plot middle six plants' fruits were selected to record data. Data were analyzed statistically and means were compared by the Least Significant Difference (LSD) test. 


\section{Results and Discussion}

Fruit quality parameters

Pulp weight: Pulp weight is an important parameter for canning industry. Wide variation was found as to the different levels of boron and zinc in this respect. It was as low as $77.5 \%$ in control to as high as $87.4 \%$ in $2.5 \mathrm{~kg} \mathrm{~B}+6 \mathrm{~kg} \mathrm{Zn/ha}$ (Table 1). Pulp weight of the fruits also varied due to the significant effect of cowdung. The highest pulp weight (83.9\%) was recorded in $15 \mathrm{t} /$ ha cowdung flollowed by $20 \mathrm{t} / \mathrm{ha}$ cowdung (83.9\%). whereas it was the lowest $(78.9 \%)$ in without cowdung (Table 2). On the other hand, statistical difference was exhibited due to the combined effect of boron, zinc, and cowdung. The fruits which were produced with $2.5 \mathrm{~kg} \mathrm{~B}+6 \mathrm{~kg} \mathrm{Zn/ha}$ and $20 \mathrm{t} / \mathrm{ha}$ cowdung gave the highest pulp weight (90.2\%) followed by $2.5 \mathrm{~kg} \mathrm{~B}+6 \mathrm{~kg} \mathrm{Zn} / \mathrm{ha}$ and $15 \mathrm{t} / \mathrm{ha}$ cowdung (89.4\%), which was statistically identical (Table 3). Whereas, it was the lowest $(76.7 \%)$ in without boron, zinc, and cowdung. This might be due to higher accumulation of assimilates to the fruits. Puspha (2004) noted higher rind thickness under 100 percent recommended dose of fertilizers with biofertilizers.

Dry matter content: It was observed that dry matter content of the fruits increased progressively with increased doses of boron and zinc. However, it ranged from $4.76 \%$ in control to $5.59 \%$ in $2.5 \mathrm{~kg} \mathrm{~B}+6 \mathrm{~kg} \mathrm{Zn/ha.} \mathrm{Different}$ levels of cowdung also followed the similar trend of main effect of boron and zinc regarding this parameter (Table 2). The combined effect of boron, zinc, and cowdung revealed the significant variation. However, the dry matter content differed from 4.96 to $5.82 \%$. The fruits produced in plants receiving $2.5 \mathrm{~kg} \mathrm{~B}+6 \mathrm{~kg} \mathrm{Zn/ha}$ and $20 \mathrm{t} / \mathrm{ha}$ cowdung gave the highest dry matter content (Table 3). On the contrary, the lowest dry matter content was recorded in without boron, zinc, and cowdung. Balasubramaniam et al. (1998) stated that dry matter content of the fruits was favourably influenced by the application of $100 \%$ soil test based NPK combined with borax (10 kg/ha), zinc sulphate (50 $\mathrm{kg} / \mathrm{ha}$ ), and coir pith (5 t/ha).

Total soluble solid: Varied levels of boron and zinc had profound influence on TSS (\%) content of fruit. It ranged from 4.02 to 4.47 (Table I). TSS content of the fruit also markedly varied due to the main effect of cowdung. The highest TSS content (4.32\%) was observed in fruits produced with 20 t/ha cowdung, whereas it was the lowest (4.02\%) in without cowdung. The fruits produced with $2.5 \mathrm{~kg} \mathrm{~B}+6 \mathrm{~kg} \mathrm{Zn/ha} \mathrm{and} 10 \mathrm{t} / \mathrm{ha}$ cowdung and $2.5 \mathrm{~kg} \mathrm{~B}+6 \mathrm{~kg} \mathrm{Zn} / \mathrm{ha}$ and 15 $\mathrm{t} /$ ha cowdung gave the highest TSS content (4.60\%) followed by $2.5 \mathrm{~kg} \mathrm{~B}+6 \mathrm{~kg}$ $\mathrm{Zn} / \mathrm{ha}$ and $20 \mathrm{t} / \mathrm{ha}$ cowdung (4.50\%). But the lowest ISS content $(3.80 \%)$ was found in without boron, zinc, and cowdung (Table 3). 
Table 1. Main effect of boron and zinc on fruit quality of tomato.

\begin{tabular}{c|c|c|c|c|c|c|c|c|c}
\hline Treatment & Pulp wt (\%) & $\begin{array}{c}\text { Dry matter } \\
\text { content (\%) }\end{array}$ & TSS (\%) & $\begin{array}{c}\text { Ascorbic } \\
\text { acid } \\
(\mathrm{mg} / 100 \mathrm{~g})\end{array}$ & $\begin{array}{c}\text { Lycopene } \\
\text { content } \\
(\mu \mathrm{g} / 100 \mathrm{~g})\end{array}$ & $\begin{array}{c}\text { Chlorophyll- } \\
\mathrm{a}(\mu \mathrm{g} / 100 \mathrm{~g})\end{array}$ & $\begin{array}{c}\text { Chlorophyll- } \\
\mathrm{b}(\mu \mathrm{g} / 100 \mathrm{~g})\end{array}$ & $\begin{array}{c}\text { Boron } \\
\text { content } \\
(\mu \mathrm{g} / \mathrm{g})\end{array}$ & $\begin{array}{c}\text { Zinc content } \\
(\mu \mathrm{g} / \mathrm{g})\end{array}$ \\
\hline $\mathrm{B}_{0} \mathrm{Zn}_{0}$ & 77.52 & 4.78 & 4.02 & 8.88 & 43.25 & 17.52 & 25.00 & 26.75 \\
$\mathrm{~B}_{1.5} \mathrm{Zn}_{2}$ & 80.85 & 5.00 & 4.10 & 9.32 & 67.75 & 27.22 & 39.50 & 29.00 & 39.75 \\
$\mathrm{~B}_{2} \mathrm{Zn}_{4}$ & 82.99 & 5.28 & 4.25 & 9.97 & 88.50 & 37.25 & 54.00 & 32.00 & 41.75 \\
$\mathrm{~B}_{2.5} \mathrm{Zn}_{6}$ & 87.37 & 5.59 & 4.47 & 10.71 & 123.00 & 39.50 & 57.50 & 34.00 & 48.25 \\
\hline $\mathrm{LSD}(1 \%)$ & 1.40 & 0.11 & 0.11 & - & 1.96 & 0.56 & 0.84 & 0.56 & 0.59 \\
$\mathrm{CV}(\%)$ & 1.52 & 1.94 & 2.37 & 2.57 & 2.17 & 1.65 & 1.70 & 1.64 \\
\hline
\end{tabular}

Table 2. Main effect of cowdung on fruit quality of tomato.

\begin{tabular}{|c|c|c|c|c|c|c|c|c|c|}
\hline $\begin{array}{l}\text { Dose of } \\
\text { cowdung } \\
\text { (t/ha) }\end{array}$ & Pulp wt. (\%) & $\begin{array}{c}\text { Dry matter } \\
\text { content (\%) }\end{array}$ & TSS (\%) & $\begin{array}{c}\text { Ascorbic } \\
\text { acid } \\
(\mathrm{mg} / 100 \mathrm{~g})\end{array}$ & $\begin{array}{l}\text { Lycopene } \\
\text { content } \\
(\mu \mathrm{g} / 100 \mathrm{~g})\end{array}$ & $\begin{array}{c}\text { Chlorophyll- } \\
\text { a ( } \mu \mathrm{g} / 100 \mathrm{~g})\end{array}$ & $\begin{array}{l}\text { Chlorophyll- } \\
\text { b ( } \mu \mathrm{g} / 100 \mathrm{~g})\end{array}$ & $\begin{array}{c}\text { Boron } \\
\text { content } \\
(\mu \mathrm{g} / 100 \mathrm{~g})\end{array}$ & $\begin{array}{c}\text { Zinc content } \\
(\mu \mathrm{g} / 100 \mathrm{~g})\end{array}$ \\
\hline 0 & 78.89 & 4.95 & 4.02 & 9.23 & 66.25 & 26.97 & 38.25 & 29.50 & 39.75 \\
\hline 10 & 81.98 & 5.13 & 4.22 & 9.72 & 81.75 & 30.55 & 44.50 & 30.25 & 40.50 \\
\hline 15 & 83.94 & 5.24 & 4.27 & 9.81 & 84.25 & 30.95 & 45.25 & 31.00 & 42.00 \\
\hline 20 & 83.91 & 5.34 & 4.32 & 10.13 & 90.25 & 33.02 & 48.00 & 31.50 & 42.75 \\
\hline CV (\%) & 1.52 & 1.94 & 2.37 & 2.57 & 2.17 & 1.65 & 1.70 & 1.64 & 1.21 \\
\hline \multicolumn{2}{|c|}{$\begin{array}{l}\mathrm{B}_{0}=0 \mathrm{~kg} \mathrm{~B} / \mathrm{ha} \\
\mathrm{B}_{1.5}=\mathrm{kg} \mathrm{B} / \mathrm{ha} \\
\mathrm{B}_{2.0}=2.0 \mathrm{~kg} \mathrm{~B} / \mathrm{ha} \\
\mathrm{B}_{2.5}=2.5 \mathrm{~kg} \mathrm{~B} / \mathrm{ha}\end{array}$} & \multicolumn{3}{|c|}{$\begin{array}{l}\mathrm{Zn}_{0}=0 \mathrm{~kg} \mathrm{Zn/ha} \\
\mathrm{Zn}_{2}=2 \mathrm{kgZn} / \mathrm{ha} \\
\mathrm{Zn}_{4}=4 \mathrm{~kg} \mathrm{Zn/ha} \\
\mathrm{Zn}_{6}=6 \mathrm{~kg} \mathrm{Zn/ha}\end{array}$} & & & & & \\
\hline
\end{tabular}


Ascorbic acid: Ascorbic acid content of the fruit was significantly influenced by the different levels of boron and zinc. It varied from 8.88 to $10.71 \mathrm{mg} / 100 \mathrm{~g}$. The maximum was recorded with $2.5 \mathrm{~kg} \mathrm{~B}+6 \mathrm{~kg} \mathrm{Zn/ha} \mathrm{lollowed} \mathrm{by} 2 \mathrm{~kg} \mathrm{~B}+4 \mathrm{~kg}$ $\mathrm{Zn} / \mathrm{ha}$ (9.97 mg/100g), which was statistically significant (Table 1). The minimum was recorded from the fruits produced without boron and zinc application. Diverse variation was found among the cowdung levels in respect of ascorbic acid content. It was as low as $9.23 \mathrm{mg} / 100 \mathrm{~g}$ in control to as high as $10.13 \mathrm{mg} / 100 \mathrm{~g}$ in $20 \mathrm{t} /$ ha cowdung (Table 2).

On the other hand, distinct variation was visible among the treatment combinations as to that from the control. The fruits produced with the highest level of boron, zinc, and cowdung (2.5 kg B $+6 \mathrm{~kg} \mathrm{Zn/ha} \mathrm{and} 20 \mathrm{t} / \mathrm{ha}$ cowdung) gave the highest $(11.20 \mathrm{mg} / 100 \mathrm{~g})$ ascorbic acid followed by $2.5 \mathrm{~kg} \mathrm{~B}+6 \mathrm{Kg}$ Zn/ha and 15 t/ha cowdung (10.99 mg/100g), which was statistically identical. On the contrary, the lowest value was recorded in without application of boron, zinc, and cowdung. The rest treatment combinations demonstrated ascorbic acid content from 9.10 to $10.00 \mathrm{mg} / 100 \mathrm{~g}$. Dube et al. (2004) recorded the highest ascorbic acid content with the soil application of zinc sulphate and borax @ 10 and $20 \mathrm{~kg} / \mathrm{ha}$, respectively, in tomato. Kumar (2003) reported that application of FYM 25 t/ha 150\% NPK (150:112: $82.5 \mathrm{~kg} / \mathrm{ha}$ NPK) in tomato was the best for obtaining higher values of quality parameters.

Lycopene content: It was observed that lycopene content of the fruit gradually increased with the increasing boron and zinc levels. Similar trend was also observed as to the different levels of cowdung regarding this parameter. The highest lycopene content $(90.25 \mu \mathrm{g} / 100 \mathrm{~g})$ was recorded with $20 \mathrm{t} / \mathrm{ha}$ cowdung followed by that of $15 \mathrm{t} / \mathrm{ha}$ cowdung $(84.25 \mu \mathrm{g} / 100 \mathrm{~g})$, which was statistically significant (Table 2). The lowest $(66.25 \mu \mathrm{g} / 100 \mathrm{~g})$ was noted in without cowdung. The results of the study reflected that lycopene content gradually increased with the increasing boron, zinc, and cowdung (Table 3). The highest lycopene content $(147.00 \mu \mathrm{g} / 100 \mathrm{~g})$ was noted from the fruit produced with $2.5 \mathrm{~kg} \mathrm{~B}+6 \mathrm{~kg} \mathrm{zn} / \mathrm{ha}$ and $20 \mathrm{t} / \mathrm{ha}$ cowdung followed by $2.5 \mathrm{~kg} \mathrm{~B}+6 \mathrm{~kg} \mathrm{Zn} / \mathrm{ha}$ and $15 \mathrm{t} / \mathrm{ha}$ cowdung (131.00 $\mu \mathrm{g} / \mathrm{l00g}$ ), which was statistically significant. On the contrary, the lowest (39.00 $\mu \mathrm{g} / 100 \mathrm{~g}$ ) was recorded under no application of boron, zinc, and cowdung. Dube et al. (2003) opined that zinc application significantly increased lycopene content of the tomato fruits.

Chlorophyll-a and-b: Profound variation was observed in respect of chlorophyll- a content of the fruit as to the main effect of boron and zinc application. The highest $(39.00 \mu \mathrm{g} / 100 \mathrm{~g})$ value was obtained from the treatment $2.5 \mathrm{~kg} \mathrm{~B}+6 \mathrm{~kg} \mathrm{Zn} / \mathrm{ha}$ followed by $2 \mathrm{~kg} \mathrm{~B}+4 \mathrm{~kg} \mathrm{Zn} / \mathrm{ha}(37.25 \mu \mathrm{g} / 100 \mathrm{~g})$, which 
was statistically significant. The fruits which were produced without boron and zinc had less chlorophyll- a content (Table 1). The main effect of cowdung on chlorophyll-a content was significant. It was as low as $26.97 \mu \mathrm{g} / 100 \mathrm{~g}$ in control to as high as $33.02 \mu \mathrm{g} / 100 \mathrm{~g}$ in $20 \mathrm{t} / \mathrm{ha}$ cowdung (Table 2). Remarkable variation was noted among the treatment combinations regarding this aspect. The fruit produced with $2.5 \mathrm{~kg} \mathrm{~B}+6 \mathrm{~kg} \mathrm{Zn/ha}$ and $20 \mathrm{t} / \mathrm{ha}$ cowdung gave the maximum chlorophyll- a $(42.00 \mu \mathrm{g} / 100 \mathrm{~g})$, whereas it was the minimum $(17.00 \mu \mathrm{g} / 100 \mathrm{~g})$ in control and with $10 \mathrm{t} / \mathrm{ha}$ cowdung (Table 3). This might be due to balanced application of boron and zinc, and cowdung which improved uptake of nutrients and increase chlorophyll content. Singh and Singh (2004) reported that zinc application increased chlorophyll content and raised the concentration of $\mathrm{Zn}, \mathrm{Ca}$, $\mathrm{Mg}, \mathrm{K}$, and $\mathrm{P}$ in tissues.

The chlorophyll- $\mathrm{b}$ content of the fruit differed due to the varied levels of boron and zinc. The highest $(57.00 \mu \mathrm{g} / 100 \mathrm{~g})$ was recorded with $2.5 \mathrm{~kg} \mathrm{~B}+6 \mathrm{~kg}$ $\mathrm{Zn} / \mathrm{ha}$ followed by $2 \mathrm{~kg} \mathrm{~B}+4 \mathrm{~kg} \mathrm{Zn} / \mathrm{ha}(54.00 \mu \mathrm{g} / 100 \mathrm{~g})$, which was statistically significant. The lowest $(25.00 \mu \mathrm{g} / 100 \mathrm{~g})$ was found in without boron and zinc (Table 1). Similar trend was also observed due to the main effect of cowdung as was evident in main effect of boron and zinc regarding this parameter. It ranged from 38.25 to $48.00 \mu \mathrm{g} / 100 \mathrm{~g}$ (Table 2). Combination of boron, zinc, and cowdung had significant influence on chlorophyll- $b$ content. The fruit produced with $2.5 \mathrm{~kg} \mathrm{~B}+6 \mathrm{~kg} \mathrm{Zn/ha}$ and $20 \mathrm{t} / \mathrm{ha}$ cowdung had the highest chlorophyll-b content ( $61.00 \mu \mathrm{g} / 100 \mathrm{~g}$ ) followed by $2.5 \mathrm{~kg} \mathrm{~B}+6 \mathrm{~kg} \mathrm{Zn/ha} \mathrm{and} 15 \mathrm{t} / \mathrm{ha}$ cowdung $(59.00 \mu \mathrm{g} / 100 \mathrm{~g})$, which was statistically significant. On the contrary, the lowest $(23.00 \mu \mathrm{g} / 100 \mathrm{~g})$ was recorded in without boron and zinc, which was statistically significant from those of the other treatment combinations (Table 3).

\section{Boron and zinc contents}

Boron content in tomato gradually increased with the increasing levels of boron and zinc application. It was as low as $26.75 \mu \mathrm{g} / \mathrm{g}$ in control to as high as 34.00 ppm in $2.5 \mathrm{~kg} \mathrm{~B}+6 \mathrm{~kg} \mathrm{Zn/ha} \mathrm{(Table} \mathrm{1).} \mathrm{Different} \mathrm{levels} \mathrm{of} \mathrm{cowdung}$ significantly influenced boron content. The highest value $(31.50 \mu \mathrm{g} / \mathrm{g})$ was recorded with $20 \mathrm{t} / \mathrm{ha}$ cowdung closely followed by $15 \mathrm{t} / \mathrm{ha}$ cowdung (31.00 $\mu \mathrm{g} / \mathrm{g})$, whereas it was the lowest $(29.50 \mu \mathrm{g} / \mathrm{g})$ in without cowdung application (Table 2). On the other hand, treatment combinations had pronounced effect as to the boron content of the fruit. It ranged from 26.00 to $36.00 \mu \mathrm{g} / \mathrm{g}$. The maximum boron content was recorded in the fruit produced with application of $2.5 \mathrm{~kg} \mathrm{~B}+6$ $\mathrm{kg} \mathrm{Zn/ha}$ and $20 \mathrm{t} / \mathrm{ha}$ cowdung. The minimum value was noted in the fruits produced with no application of boron, zinc, and cowdung (Table 3). Yadav et al. 
(2001) noted the highest concentration of boron and zinc with $4 \mathrm{~kg}$ boron and 20 $\mathrm{kg} \mathrm{ZnSO}_{4}$, respectively.

Zinc content of the fruit differed significantly due to the different levels of boron and zinc. The highest zinc content $(48.25 \mu \mathrm{g} / \mathrm{g})$ was found in $2.5 \mathrm{~kg} \mathrm{~B}+6$ $\mathrm{kg} \mathrm{Zn/ha} \mathrm{followed} \mathrm{by} 2 \mathrm{~kg} \mathrm{~B}+4 \mathrm{~kg} \mathrm{Zn/ha}(41.75 \mu \mathrm{g} / \mathrm{g})$, which was statistically significant. The lowest value $(35.75 \mu \mathrm{g} / \mathrm{g})$ was recorded from without boron and zinc (Table 1). Different levels of cowdung was found to affect significantly the zinc content of the fruit. It was as low as $39.75 \mu \mathrm{g} / \mathrm{g}$ in control to as high as 42.75 $\mu \mathrm{g} / \mathrm{g}$ in $20 \mathrm{t} / \mathrm{ha}$ cowdung followed by $15 \mathrm{t} / \mathrm{ha}$ cowdung (42.00 $\mu \mathrm{g} / \mathrm{g})$ (Table 2). Significant variation was noted among the combinations of boron, zinc, and cowdung regarding this aspect. The highest zinc content $(51.00 \mu \mathrm{g} / \mathrm{g})$ was recorded from the fruit produced with $2.5 \mathrm{~kg} \mathrm{~B}+6 \mathrm{~kg} \mathrm{Zn} / \mathrm{ha}$ and $20 \mathrm{t} / \mathrm{ha}$ cowdung followed by $2.5 \mathrm{~kg} \mathrm{~B}+6 \mathrm{~kg} \mathrm{Zn/ha} \mathrm{and} 15 \mathrm{t} / \mathrm{ha}$ cowdung $(50.00 \mu \mathrm{g} / \mathrm{g})$, which was statistically significant. On the other hand, the lowest value (35.00 ppm) was found in control (Table 3).

\section{Storage Performance of Fruit}

Percent marketable fruits: Marketable fruit percentage was gradually decreased with the increase in storage time in each of the storage period. On the other hand, at 30 days after storage, percent marketable fruit was gradually increased with the increased quantity of boron and zinc (Table 4). Percent marketable fruit also differed significantly due to the different levels of cowdung. Same trend was also found regarding percent marketable fruit as was observed in the main effect of boron and zinc. The combination of boron, zinc, and cowdung had pronounced influence on percent marketable fruit. It was found that the percent marketable fruit was gradually decreased with the passage of time starting from 9 days to upto 30 days at an interval of 3 days in each of the treatment combinations. However, at 30 days after storage, the percent marketable fruit ranged from 47.14 to 74.00 being the lowest in control and highest in $2.5 \mathrm{~kg} \mathrm{~B}+6 \mathrm{~kg} \mathrm{Zn} / \mathrm{ha}$ and 20 t/ha cowdung. The reason for higher marketable fruit might he explained in the way that balanced boron, zinc, and cowdung reduces the microbial activities. Kocevski et al. (1997) stated that boron influenced the defenses against plant diseases.

Shelf life: It was found that shelf life was gradually increased with the increased doses of boron and zinc. Shelf life was found the highest (16.5 days) in $2.5 \mathrm{~kg} \mathrm{~B}+6$ $\mathrm{kg} \mathrm{Zn/ha} \mathrm{and} \mathrm{the} \mathrm{lowest} \mathrm{(9.0} \mathrm{days)} \mathrm{in} \mathrm{without} \mathrm{boron} \mathrm{and} \mathrm{zinc} \mathrm{(Table} \mathrm{4).} \mathrm{On} \mathrm{the}$ other hand, shelf life varied due to the main effect of cowdung. It ranged from 11.25 to 13.50 days being the highest in $20 \mathrm{t} / \mathrm{ha}$ cowdung and the lowest in control (Table 5). 
Table 3. Combined effect of boron and zinc and cowdung on fruit quality of tomato.

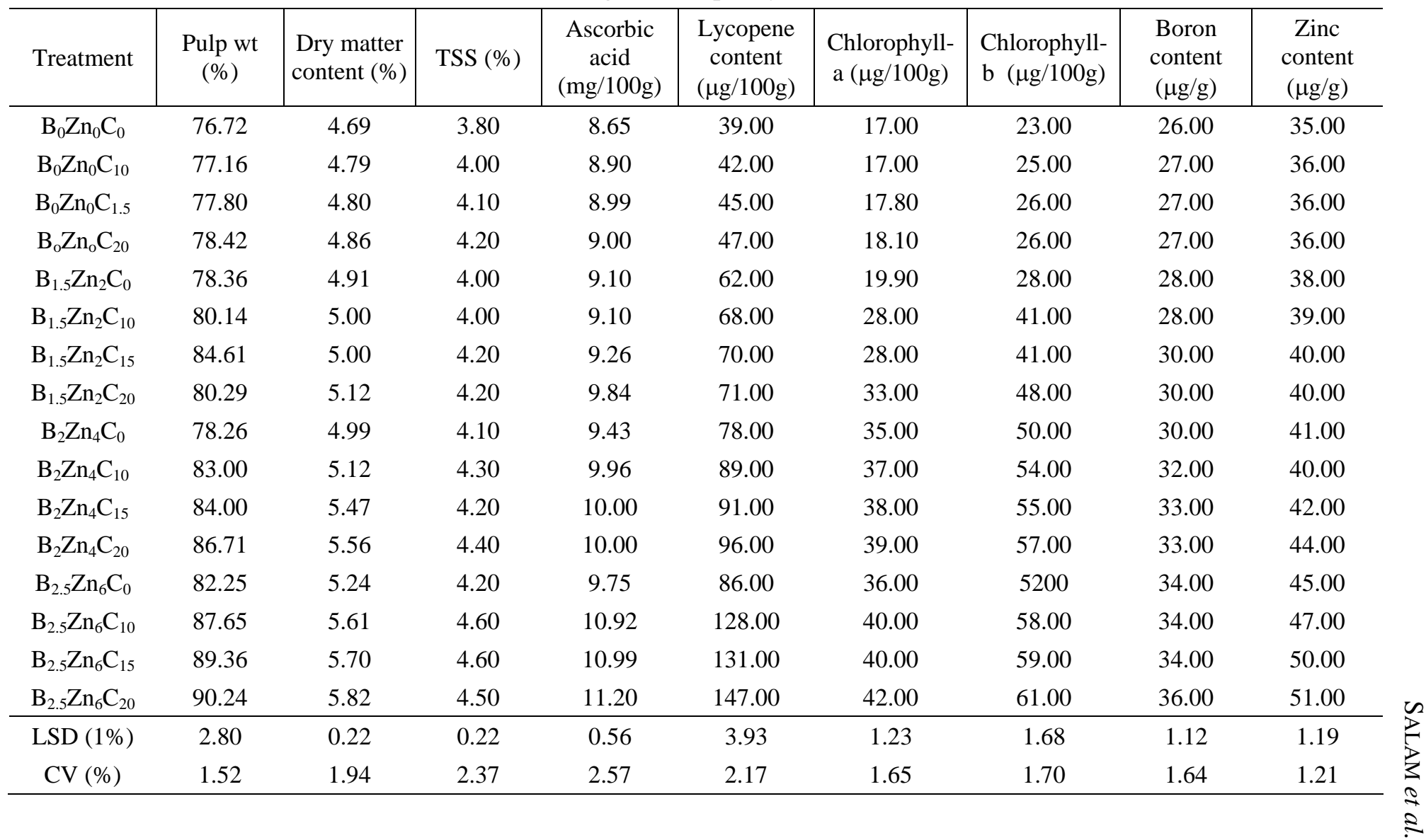


Table 4. Main effect of boron and zinc on \% marketable fruit of tomato during storage.

\begin{tabular}{|c|c|c|c|c|c|c|c|c|c|}
\hline \multirow{2}{*}{ Treatment } & \multicolumn{8}{|c|}{ \% Marketable fruit at days after storage (DAS) } & \multirow{2}{*}{ Shelf life (Days) } \\
\hline & 9 & 12 & 15 & 18 & 21 & 24 & 27 & 30 & \\
\hline $\mathrm{B}_{0} \mathrm{Zn}_{0}$ & 98.1 & 84.7 & 70.3 & 60.3 & 53.0 & 49.1 & 48.0 & 48.0 & 9.0 \\
\hline $\mathrm{B}_{1.5} \mathrm{Zn}_{2}$ & 100.0 & 94.6 & 81.1 & 70.1 & 63.2 & 58.3 & 55.8 & 55.8 & 11.3 \\
\hline $\mathrm{B}_{2} \mathrm{Zn}_{4}$ & 100.0 & 100.0 & 90.9 & 78.6 & 73.3 & 70.6 & 68.7 & 66.2 & 13.3 \\
\hline $\mathrm{B}_{2.5} \mathrm{Zn}_{6}$ & 100.0 & 100.0 & 100.0 & 92.7 & 80.5 & 74.7 & 72.3 & 70.6 & 16.5 \\
\hline LSD (1\%) & 1.40 & 1.12 & 0.84 & 0.88 & 1.22 & 1.12 & 0.98 & 1.44 & 0.56 \\
\hline $\mathrm{CV}(\%)$ & 1.26 & 1.05 & 0.88 & 1.04 & 1.61 & 1.58 & 1.43 & 2.14 & 4.00 \\
\hline able $5 \mathrm{M}$ & fect of & $\operatorname{lng} 0$ & (1) & ruit of $\mathbf{t}$ & o durin & & & & \\
\hline \multirow{2}{*}{$\begin{array}{l}\text { Dose of } \\
\text { cowdung }\end{array}$} & \multicolumn{8}{|c|}{ \% Marketable fruit at days after storage (DAS) } & \multirow{2}{*}{ Shelf life (Days) } \\
\hline & 9 & 12 & 15 & 18 & 21 & 24 & 27 & 30 & \\
\hline 0 & 98.11 & 90.61 & 80.94 & 69.16 & 63.46 & 58.65 & 57.54 & 57.07 & 11.3 \\
\hline 10 & 100.00 & 93.58 & 83.68 & 73.82 & 66.80 & 62.34 & 60.63 & 58.72 & 12.5 \\
\hline 15 & 100.00 & 97.29 & 86.80 & 77.19 & 69.75 & 65.98 & 62.84 & 61.53 & 12.8 \\
\hline 20 & 100.00 & 97.71 & 90.82 & 81.46 & 69.99 & 65.60 & 63.81 & 63.19 & 13.5 \\
\hline LSD (1\%) & 1.40 & 1.12 & 0.84 & 0.88 & 1.22 & 1.12 & 0.98 & 1.44 & 0.56 \\
\hline CV (\%) & 1.26 & 1.05 & 0.88 & 1.04 & 1.61 & 1.58 & 1.43 & 2.14 & 4.00 \\
\hline
\end{tabular}


Table 6. Combined effect of boron and zinc and cowdung on \% marketable fruit of tomato during storage.

\begin{tabular}{|c|c|c|c|c|c|c|c|c|}
\hline \multirow{2}{*}{ Treatment } & \multicolumn{8}{|c|}{ \% Marketable fruit at days after storage (DAS) } \\
\hline & 9 & 12 DAS & 15 & 18 & 21 & 24 & 27 & 30 \\
\hline $\mathrm{B}_{0} \mathrm{Zn}_{0} \mathrm{C}_{0}$ & 92.46 & 72.46 & 65.48 & 51.26 & 50.36 & 47.14 & 47.14 & 47.14 \\
\hline $\mathrm{B}_{0} \mathrm{Zn}_{0} \mathrm{C}_{15}$ & 100.00 & 89.17 & 71.36 & 63.13 & 56.42 & 52.14 & 48.00 & 48.00 \\
\hline $\mathrm{B}_{0} \mathrm{Zn}_{0} \mathrm{C}_{20}$ & 100.00 & 90.86 & 76.17 & 68.36 & 52.19 & 48.92 & 48.92 & 48.92 \\
\hline $\mathrm{B}_{1.5} \mathrm{Zn}_{2} \mathrm{C}_{10}$ & 100.00 & 88.21 & 76.24 & 66.12 & 60.86 & 57.12 & 53.42 & 53.42 \\
\hline $\mathrm{B}_{1.5} \mathrm{Zn}_{2} \mathrm{C}_{15}$ & 100.00 & 100.00 & 85.00 & 72.16 & 66.00 & 62.00 & 59.00 & 59.00 \\
\hline $\mathrm{B}_{1.5} \mathrm{Zn}_{2} \mathrm{C}_{20}$ & 100.00 & 100.00 & 87.14 & 73.49 & 67.52 & 63.18 & 59.86 & 59.86 \\
\hline $\mathrm{B}_{2} \mathrm{Zn} 4 \mathrm{C}_{0}$ & 100.00 & 100.00 & 82.48 & 71.46 & 67.12 & 64.36 & 62.18 & 62.18 \\
\hline $\mathrm{B}_{2} \mathrm{Zn}_{4} \mathrm{C}_{10}$ & 100.00 & 100.00 & 90.36 & 78.46 & 73.00 & 69.12 & 69.12 & 64.33 \\
\hline $\mathrm{B}_{2.5} \mathrm{Zn}_{6} \mathrm{C}_{10}$ & 100.00 & 100.00 & 100.00 & 92.46 & 80.18 & 75.13 & 72.00 & 69.16 \\
\hline $\mathrm{B}_{2.5} \mathrm{Zn}_{6} \mathrm{C}_{15}$ & 100.00 & 100.00 & 100.00 & 93.00 & 81.46 & 76.00 & 73.16 & 71.00 \\
\hline $\mathrm{B}_{2.5} \mathrm{Zn}_{6} \mathrm{C}_{20}$ & 100.00 & 100.00 & 100.00 & 100.00 & 82.26 & 75.20 & 74.00 & 74.00 \\
\hline LSD (1\%) & 2.80 & 2.25 & 1.68 & 1.75 & 2.45 & 2.25 & 1.97 & 1.44 \\
\hline CV (\%) & 1.26 & 1.05 & 0.88 & 1.04 & 1.61 & 1.58 & 1.43 & 2.14 \\
\hline
\end{tabular}




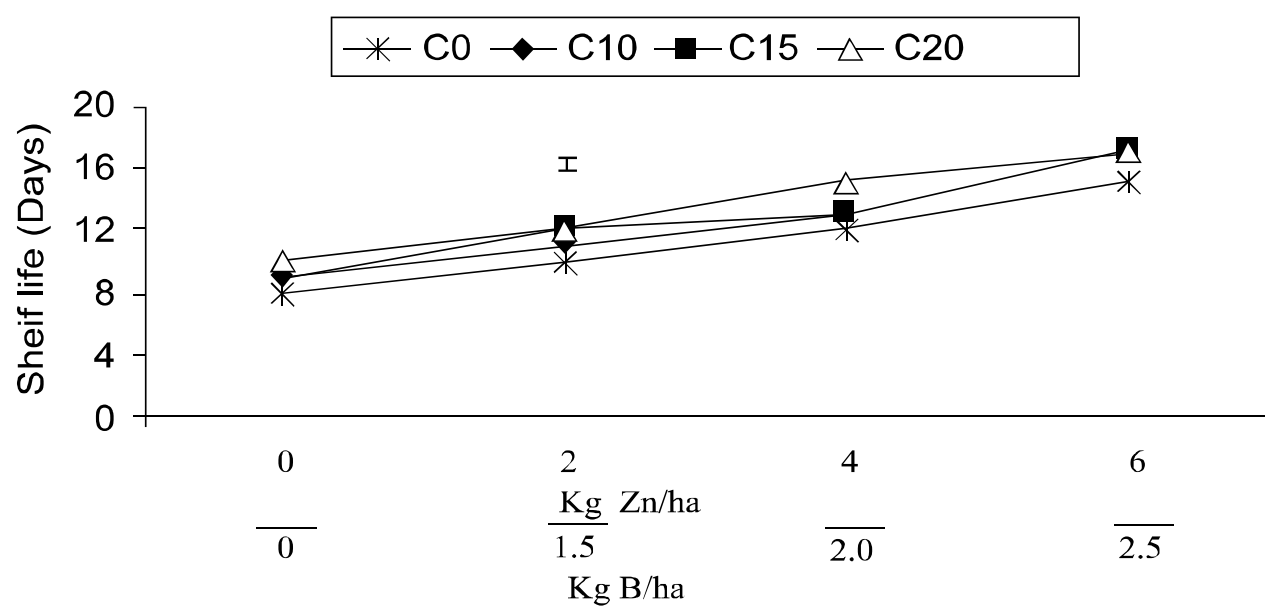

Fig. 1. Combined effect of boron and zinc at different levels of cowdung on shelf life of tomato. The vertical bar indicates LSD at 0.01 level. $\mathrm{C}_{0}=$ Cowdung $0 \mathrm{t} / \mathrm{ha}, \mathrm{C}_{10}=$ Cowdung $10 \mathrm{t} / \mathrm{ha}, \mathrm{C}_{15}=$ Cowdung $15 \mathrm{t} / \mathrm{ha}, \mathrm{C}_{20}=$ Cowdung 20 t/ha.

The treatment combinations of boron, zinc, and cowdung had profound influence on shelf life of tomato. A sharp increasing trend of shelf life was found with the increasing levels of boron, zinc, and cowdung. The lowest shelf life (8.00 days) was observed in control and the highest (17.00 days) in $2.5 \mathrm{~kg} \mathrm{~B}+6 \mathrm{~kg} \mathrm{Zn/ha} \mathrm{and}$ $20 \mathrm{t} / \mathrm{ha}$ cowdung and it was statistically insignificant with $2.5 \mathrm{~kg} \mathrm{~B}+6 \mathrm{~kg} \mathrm{Zn/ha}$ and 15 t/ha cowdung and $2.5 \mathrm{~kg} \mathrm{~B}+6 \mathrm{~kg} \mathrm{Zn/ha}$ and 10 t/ha cowdung (Fig. 1). This might be due to balanced boron, zinc, and cowdung improved the membrane stability resulting higher shelf life. Yamouchi et al. (1986) reported that boron helps maintain membrane stability. Smit and Combrink (2004) stated that at low level of boron, tomato fruit lacked firmness.

\section{Conclusion}

Based on the findings of the investigation, it may be concluded that to improve tomato quality and maintain the soil health in good condition, application of 2.5 $\mathrm{kg} \mathrm{B}+6 \mathrm{~kg} \mathrm{Zn/ha}$ and $20 \mathrm{t} / \mathrm{ha}$ cowdung is congenial for Gazipur soil of Bangladesh.

\section{References}

Balasubramaniam, P., A. K. Mani, P. Duraisamy and M. Kandaswami. 1998. Effect of organic and inorganic nutrients on the yield and uptake of tomato. South Indian Hort. 46 (3-6): 143-147. 
BBS. 2007.Year Book of Agricultural Statistics of Bangladesh. Bangladesh Bureau of Statistics, Ministry of Planning, Govt. of the Peoples' Republic of Bangladesh, Dhaka. p.17.

Demoranvillc, C.J. and K. H. Deubert. 1987. Effect of commercial calcium-boron and manganese- zinc formulations on fruit set of cranberries. J. Hort. Sci. 62: 163-169.

Duhe, B. K.. S. Pratima and C. Chatterjee. 2003. Effects of zinc on the yield and quality of tomato. Indian J. Hort. 60(1): 59-63.

Dube, B. K., S. Pratima and C. Chatterjee. 2004. Effects of boron and zinc on the yield and quality of tomato. Indian J. Hort. 61(1): 48-52.

Hunter, A. H. 1980. Soil Fertility Analytical Service in Bangladesh” - Consultancy report, BJRI project phase II, BARC, Dhaka , Bangladesh. p.53.

Katyal, J.C. and N.S. Randhawa. 1983. Micronutrients. FAO Fertilizer and PlantNutrition Bulletin. pp. 3-76.

Kocevski, G. V., N. I). Jakimov, M. M. Jekic and R. L. Koleva. 1997. The effect of NPK. $\mathrm{Mg}$ and $\mathrm{B}$ on the yield, morphological characteristics and quality characteristics of industrial tomatoes. Acta Hort. 462: 183-186.

Kumar, P. 2003. Effect of integrated nutrient management on sustainable cabbage and tomato production. Ph.D. Thesis. Department of Vegetable Crops, Dr. Y.S. Parmar University of Horticulture \& Forestry, Nauni, Solan.282p.

Magalhaes, J.R. I)c., C.E.W.L. Solwa Dc. and P.H. Monnerat.1980. Levels and methods of boron application in tomatoes. Pesquisa Agropecuria Brasilesia 10 (2) : 153-157 [Cited from Hort. Abstr. 50(4): 2031, 19811.

Mondal, M. F. 2000. Production and Storage of Fruits (in Bangla). Published by Mrs. Afia Mondal, BAU Campus, Mymensingh-2202. 312 p.

Nagata, M., K. Dan and I.Yamashita. 1992. Simple method for simultaneous determination of chlorophyll and carotenoids in tomato. J. Japan Soc. Hort. Sci. 61(2): 686-687.

Puspha. U. 2004. Influence of graded levels of NPK with and without microbial inoculants on growth, yield and quality of tomato (Lycopersicon esculentum) leaf curl virus resistant lines. M.Sc. Thesis, University of Agricultural Sciences, Bangalore, India. 121 p.

Rahayu,Y.S, V. Rombeld, F. Bangerth, D. Neilsen, B.Fallahi, G. Neilsen and F. Peryea. 2001. Does zinc nutrition affect calcium disorder of fruits. Acta Hort. 564:135-143.

Ranganna, S. 1994. Manual of Analisis of Fruit and Vegetable Products. Tata McGrawlull Publishing Company Limitted, New Delhi, 11-12 p.

Shukla, V. and L. B. Naik. 1993. Agro-techniques for Solanaceous Vegetables. In: Vegetable Crops: Part-l, Advances in Horticulture. Vol. 5, Eds: K. L. Chadha and G. Kalloo, Maihotra Publishing House, New Delhi, India. p.371

Singh. H. P. and T. N. Singh. 2004. Effect of sources and levels of Zn on growth yield and mineral composition of rice in Alkali soil. Indian J. Plant Physiol. 4: 378-382. 
Smit. J. N. and N. J. J. Combrink. 2004. The effect of boron levels in nutrient solutions on fruit production and quality of greenhouse tomatoes. S. Afr. J. Plant Soil 21(3): 188-191.

Yadav, P. V. S., T. Abha, N. K. Sharma and A. Tikkoo. 2001. Effect of zinc and boron application on yield, concentration and their uptake by tomato. Haryana J. Hort. Sci. 30(3-4): 24 1-253.

Yamouchi. T., T. Hara and Y. Sonodoa. 1986. Distribution of calcium and boron in the pectin fraction of tomato leaf cell wall. Plant Cell Physiol. 27: 729-732. 